\title{
Asymptomatic Malaria Carriage in South-Western Burkina Faso: An Epidemiological Analysis
}

\author{
Issaka Zongo'), Anthony Somé(1), Eric Nagaonlé Somé1), Mamadou Ouattara3), Amal \\ Dahounto" $^{2)}$, Cédric Pennetier²), Nicolas Moiroux ${ }^{1,2)}$, Roch K. Dabiréé)
}

\author{
1)Institut de Recherche en Sciences de la Santé (IRSS), BP 545, Bobo-Dioulasso, Burkina Faso \\ 2)Institut de Recherche pour le Développement - Maladies Infectieuses et Vecteurs Ecologie, Génétique, \\ Evolution et Contrôle (IRD - MIVEGEC), BP 6450134394 Montpellier cedex 5, France \\ 3)Centre de Recherche en Santé à Nouna (CRSN), BP 02 Nouna, Burkina Faso
}

\section{ABSTRACT}

Background: Burkina Faso is challenged by rise in malaria incidence and insecticide and drug resistance. We investigated the prevalence of asymptomatic infection of Plasmodium falciparum. over three surveys.

Subjects dan Method: We conducted repeated cross-sectional surveys in September and December 2016 and June 2017 in Diebougou health district. An initial census identified 4,028 subjects aged 6 months to 18 years. The independent variables included the age or date of birth, dependant were the area of residence, the use of bed nets, presence of not of parasites, the period of the surveys and the presence or absence of clinical signs/symptoms/fever, the gender. We used electronic case report forms for data collection, then uploaded into electronic tablets PCs, transferred to a central server. Data were analyzed with $\mathrm{R}$ version 3.4.3 software. Baseline characteristics were described using descriptive statistics. A bivariate analysis was done to describe the overall malaria prevalence using Chi-squared or Fisher Exact test. Simple and multiple logistic regressions served to determine effect of socio-demographic characteristics and season on both symptomatic and asymptomatic malaria cases.

Results: Three malaria active case detection surveys were conducted on 2,839, 2,594 and 2,337 eligible subjects in September 2016, December 2016, and June 2017 respectively. There was high proportion of parasitemia ranging from $31.6 \%$ to $43.5 \%$ whereas malaria clinical cases ranged from $6.8 \%$ in June to $23.81 \%$ in September. Age, gender, season, and village variables were significantly associated with asymptomatic malaria carriage. Sleeping under a bednet the night before the survey was found to be protective against asymptomatic malaria.

Conclusion: This study has reported high prevalence of malaria infection. The young population was more concerned and September was the period of highest carriage.

Keywords: asymptomatic malaria carriage, active case detection, age.

\section{Correspondence:}

Issaka Zongo. Institut de Recherche en Sciences de la Santé, BP 545, Bobo-Dioulasso, Burkina Faso. E-mail address: zongoissakao8@gmail.com. Mobile: (+226) 70636991.

\section{Cite this as:}

Zongo I, Somé A, Somé EN, Ouattara M, Dahounto A, Pennetier C, Moiroux N, Dabiré RK (2021). Asymptomatic Malaria Carriage in South-Western Burkina Faso: An Epidemiological Analysis. J Epidemiol Public Health. 06(04): 459-471. https://doi.org/10.26911/jepublichealth.2021.06.04.07.

cc (7) (-) Journal of Epidemiology and Public Health is licensed under a Creative Commons Attribution-NonCommercial-ShareAlike 4.0 International License.

\section{BACKGROUND}

Despite the implementation of intensive malaria interventions in the past decade followed by a significant decline in malaria mortality and morbidity, the global burden of the disease remains high; World Malaria report for 2020 estimated that 229 million 
cases occurred in 2019 compared to 238 million cases in 2000 (WHO, 2020)

Malaria incidence and prevalence remain high and Burkina Faso is one of the "high burden country targeted in the "high burden high impact: a targeted malaria response" set by the World Health Organization (WHO, 2018). In 2015, malaria was the first cause of outpatient consultations (41.3\%), hospitalizations (21.4\%), death (16.4\%) (Ministry of Health, 2016a) and the main cause of illness among children (80\%) (Tiono et al., 2014).

The Global Technical Strategy for Malaria 2016-2030 was endorsed by World Health Assembly, calling for a reduction in global incidence and mortality of malaria by at least $90 \%$ by 2030 (WHO Malaria Policy Advisory Committee and Secretariat, 2015). This ambitious plan should include all types of malaria infections: clinical malaria (uncomplicated and severe malaria) and asymptomatic carriage (Marsh et al., 1995; Imbert et al., 2002; Epopa et al., 2019).

In intense and perennial transmission settings, entomological inoculation rate is high (Epopa et al., 2019) entertaining a certain level of immunity and a highly prevalent asymptomatic carriage of $\mathrm{P}$. falciparum parasites (Njama-Meya et al., 2004; Gudo et al., 2013) which are not treated most of the time except during the seasonal malaria chemoprevention campaigns among children under 5 years old; thus it poses a major challenge to efforts towards malaria control and elimination (Ganguly et al., 2013; Lindblade et al., 2013)

Asymptomatic carriage of Plasmodium falciparum is a function of the population's susceptibility to the clinical disease and is associated with the progression to clinical malaria (Bereczky et al., 2007), the number of recurrent cases, the chronic anemia, the maternal and neonatal death, the bacterial infections, the cognitive disorders and the enhanced transmission of the disease in the population (Chen et al., 2016; Tadesse et al., 2017). Asymptomatic carriers appear to be the main P. falciparum reservoir and thus sustain the transmission between seasons [16]. Studies have reported that parasites from asymptomatic individuals were even more infectious to vectors than those of clinical cases (Gouagna et al., 2004, 2007; Ouédraogo et al., 2015). In the context of insecticide-resistant area of Diébougou, we aimed at investigating the burden of asymptomatic infection of Plasmodium falciparum over several - cross-sectional surveys.

\section{SUBJECTS AND METHOD}

\section{Study Design}

We did three repeated cross-sectional surveys one just before the start of the transmission season (June 2017), one during the intensive transmission period (September 2016) and the last at the end of the transmission period (December 2016) to allow better capture of the parasite carriage over time.

\section{Study Variables}

The independent variables included the age or date of birth, dependant were the area of residence, the use of bed nets, presence of not of parasites, the period of the surveys and the presence or absence of clinical signs/symptoms/fever, the gender.

\section{Population and Sample}

The study population referred to the population of the selected villages while the targeted population was those aged form 6 months to 18 years. The surveys lasted approximately three weeks.

Recent data from neighboring area indicated that incidence of malaria was 1.2 episode per child per year (Tiono et al., 2014). The sample size of 8 clusters was calculated to detect $33 \%$ reduction in the combined arm compared to the control arm 
with $80 \%$ power, risk of error $\alpha=0.05, \mathrm{CV}=$ 0.25 with approximately 300 participants per cluster.

\section{Operational Definition of Variables}

These include: Asymptomatic carriers: Presence of Plasmodium falciparum parasite without clinical symptom/fever, symptomatic carriers: Presence of Plasmodium falciparum parasite with clinical symptom/ fever, fever: Measured axillary temperature $\geq 37.5^{\circ}$ or history of fever within 24 hours.

\section{Study Instruments}

We used case report forms which have been uploaded into electronic tablets PCs. Case report forms contains all relevant information we want to collect from the participants. Data are collected off line and once upon return at the end of the day, data are transferred to a central server from where data are extracted, corrected and re uploaded for use by the investigators.

\section{Data analysis}

Data were analyzed with $\mathrm{R}$ version 3.4.3 software. Baseline characteristics were described using descriptive statistics where categorical variables were summarized as number and valid percent and continuous variables as mean and standard deviation. A bivariate analysis was done to describe the overall malaria prevalence, asymptomatic and symptomatic cases prevalence by age group, gender, the season of data collection, long-lasting insecticide-treated bed net use using Chi-squared or Fisher Exact test. Simple and multiple logistic regressions served to determine effect of socio-demographic characteristics and season on both symptomatic and asymptomatic malaria cases.

\section{Research Ethics}

The study was approved by the Institutional Ethics Committee for Health Research of the Institut de Recherche en Sciences de la Santé (Reference number o6-2016/ CEIRES) prior to any participant was recruited. Written informed consent was obtained from all parents or guardians of children who entered the study. Participants were explaining the full scope of the study and their right to participate or not without any prejudice; participation could be stopped at any time without any explanation. Subjects diagnosed with malaria were treated per the National Malaria Control Program guideline.

\section{RESULTS}

\section{Baseline characteristics \\ Enumerated population}

Population census was undertaken prior to the study activities; 4,028 inhabitants aged 6 months to 18 years were identified in the twenty-seven selected villages. Females represented $48 \%(1,928 / 4,028)$ of the sample and children under 5 years old accounted for $26.3 \%(1,061 / 4,028)$.

\section{Characteristics of the surveyed popu- lation}

Over three-period points $70.48 \%(2,839 /$ $4,028), 64.4 \%(2,594 / 4,028)$ and $58.02 \%$ $(2,337 / 4,028)$ were respectively surveyed in September 2016, December 2016 and June 2017. There was gender balance during the first two surveys but females were most surveyed in June 2017. The most populated village was Sarambour (271 inhabitants) while the least populated was Yelbelela (91 inhabitants). Socio-demographic characteristics of participants in each cross-sectional survey are summarized in Table 1. 
Table 1. Socio-demographical characteristics of the study participants of the CSS Malaria parasite carriage

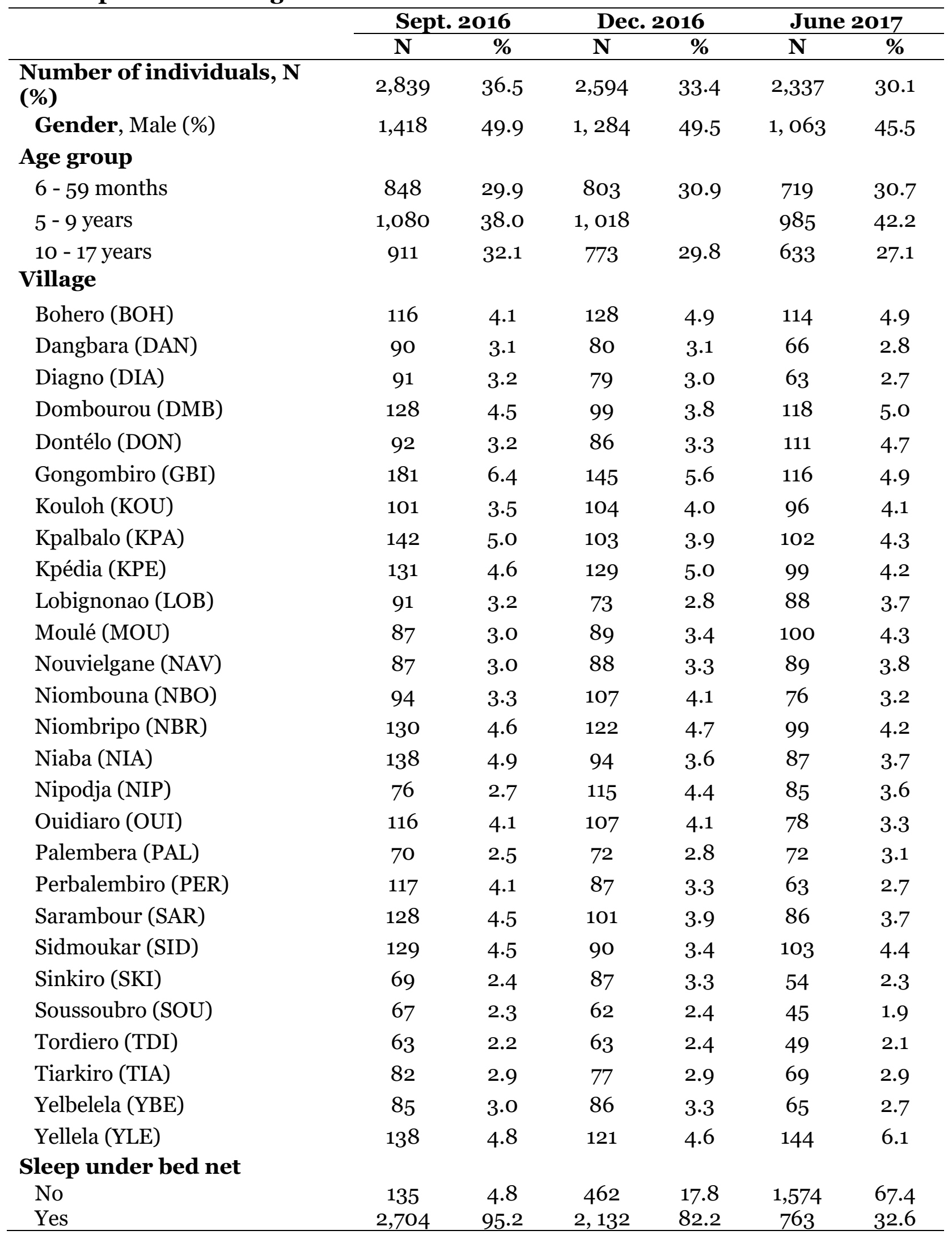


Table 2. Distribution of malaria parasite carriage per socio demographic characteristics of subjects and period of data collection

\begin{tabular}{|c|c|c|c|c|c|}
\hline \multirow{2}{*}{ Variables } & \multicolumn{2}{|c|}{$\begin{array}{l}\text { Blood smear } \\
\text { positive }\end{array}$} & \multicolumn{2}{|c|}{$\begin{array}{c}\text { Asymptomatic } \\
\text { carriers }\end{array}$} & \multirow[t]{2}{*}{$\mathbf{p}$} \\
\hline & $\mathbf{N}$ & $\%$ & $\mathbf{N}$ & $\%$ & \\
\hline Gender & & & & & $<0.001$ \\
\hline Female $(n=4,005)$ & 1,503 & $37 \cdot 5$ & 903 & 60.1 & \\
\hline Male $(n=3,765)$ & 1,559 & 41.4 & 973 & 62.4 & \\
\hline Age group & & & & & $<0.001$ \\
\hline 6 - 59 months $(\mathrm{n}=2,370)$ & 1,007 & 42.5 & 535 & 53.1 & \\
\hline $5-9$ years $(n=3,083)$ & 1,323 & 42.9 & 826 & 62.4 & \\
\hline $10-17$ years $(n=2,317)$ & 732 & 31.6 & 515 & 70.3 & \\
\hline Period & & & & & $<0.001$ \\
\hline September $2016(n=2,839)$ & 1,178 & 41.5 & 502 & 42.6 & \\
\hline December $2016(n=2,594)$ & 1,128 & 43.5 & 777 & 68.9 & \\
\hline June $2017(n=2,337)$ & 756 & 32.3 & 597 & 79.0 & \\
\hline Village of residence & & & & & $<0.001$ \\
\hline Bohero (BOH) & 98 & 27.4 & 86 & 87.7 & \\
\hline Dangbara (DAN) & 99 & 41.9 & 68 & 68.7 & \\
\hline Diagno (DIA) & 82 & 35.2 & 63 & 76.8 & \\
\hline Dombourou (DMB) & 158 & 45.8 & 106 & 67.1 & \\
\hline Dontélo (DON) & 119 & 41.2 & 79 & 66.4 & \\
\hline Gongombiro (GBI) & 171 & 38.7 & 109 & 63.7 & \\
\hline Kouloh (KOU) & 132 & 43.8 & 90 & 68.2 & \\
\hline Kpalbalo (KPA) & 145 & 41.8 & 100 & 69.0 & \\
\hline Kpédia (KPE) & 103 & 28.7 & 61 & 59.2 & \\
\hline Lobignonao (LOB) & 127 & 50.4 & 55 & $43 \cdot 3$ & \\
\hline Moulé (MOU) & 94 & 34.1 & 56 & 59.6 & \\
\hline Nouvielgane (NAV) & 79 & 29.9 & 61 & 77.2 & \\
\hline Niombouna (NBO) & 72 & 26.0 & 24 & $33 \cdot 3$ & \\
\hline Niombripo (NBR) & 158 & $45 \cdot 0$ & 66 & 41.8 & \\
\hline Niaba (NIA) & 149 & 46.7 & 115 & 77.2 & \\
\hline Nipodja (NIP) & 112 & 40.6 & 55 & 49.1 & \\
\hline Ouidiaro (OUI) & 120 & 39.9 & 67 & 55.8 & \\
\hline Palembera (PAL) & 103 & 48.1 & 61 & 59.2 & \\
\hline Perbalembiro (PER) & 142 & 53.2 & 99 & 69.7 & \\
\hline Sarambour (SAR) & 89 & 28.2 & 55 & 61.8 & \\
\hline Sidmoukar (SID) & 122 & 37.9 & 54 & 44.3 & \\
\hline Sinkiro (SKI) & 72 & $34 \cdot 3$ & 46 & 63.9 & \\
\hline Soussoubro (SOU) & 66 & 37.9 & 31 & 47.0 & \\
\hline Tordiero (TDI) & 87 & 49.7 & 52 & 59.8 & \\
\hline Tiarkiro (TIA) & 63 & 27.6 & 42 & 66.7 & \\
\hline Yelbelela (YBE) & 108 & 45.8 & 50 & 46.3 & \\
\hline Yellela (YLE) & 192 & 47.6 & 125 & 65.1 & \\
\hline Slept under bed net & & & & & $<0.001$ \\
\hline No $(n=2,171)$ & 732 & 33.7 & 560 & 76.5 & \\
\hline Yes $(n=5,599)$ & 2,330 & 41.6 & 1,316 & 56.5 & \\
\hline
\end{tabular}

Overall, 39.41\% $(3,062 / 7,770)$ of participants resulted in malaria parasite occurrence in blood smears even though most of them were asymptomatic carriers irrespective of socio-demographic parameters ( $p$ $<0.001)$. Asymptomatic carriage increased 
over age groups and period of survey from beginning of transmission season in June to the end of the transmission in December and the full transmission period (September). The highest prevalence of asymptomatic malaria (50\%) was seen in the village of Lobignonao and the lowest in Niombouna (26\%). Table 2 shows the distribution of malaria parasite carriage per sociodemographic characteristics of participants.

\section{Relationship of socio-demographic characteristics and asymptomatic carriage}

In December 2016, the participants to the survey were more likely to be asymptomatic (OR 1.99) compared to those of September 2016 while this risk was substantially reduced in June 2017 (OR 1.6). The risk of asymptomatic malaria was similar in 6-59 months and 10-17 years old groups but slightly increased in the 5-9 years old. Finally the risk of asymptomatic malaria was similar across the villages except in Perbalembiro, Niaba and Niombouna (table 3).

Table 3. Distribution of socio demographic characteristics and bed net use among asymptomatic carriers

\begin{tabular}{|c|c|c|c|c|c|c|}
\hline Characteristics & Population & n (\%) & OR (95\% CI) & $\mathbf{p}$ & OR (95\% CI) & $\mathbf{p}$ \\
\hline Period & & & & $<0.001$ & & $<\mathbf{0 . 0 0}$ \\
\hline Sept. 2016 (CSS1) & 2,839 & $502(17.68)$ & 1 & & 1 & \\
\hline Dec. 2016 (CSS2) & 2,594 & $777(29.95)$ & $\begin{array}{c}1.99(1.75 \text { to } \\
2.26)\end{array}$ & $<0.001$ & $\begin{array}{c}2.07(1.81 \text { to } \\
2.36)\end{array}$ & $<0.001$ \\
\hline June 2017 (CSS3) & 2,337 & $597(25.55)$ & $\begin{array}{c}1.60 \text { (1.40to } \\
1.83)\end{array}$ & $<0.001$ & $\begin{array}{c}1.54(1.31 \text { to } \\
1.82)\end{array}$ & $<0.001$ \\
\hline $\begin{array}{l}\text { Gender } \\
\text { Male }\end{array}$ & 3,765 & $973(25.84)$ & 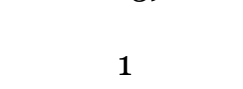 & $<0.001$ & 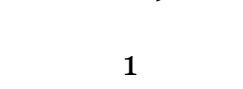 & 0.001 \\
\hline Female & 4,005 & $903(22.55)$ & $\begin{array}{c}0.84(0.75 \text { to } \\
0.93)\end{array}$ & 0.001 & $\begin{array}{c}0.84(0.75 \text { to } \\
0.93)\end{array}$ & 0.001 \\
\hline $\begin{array}{l}\text { Age group } \\
6-59 \text { months }\end{array}$ & 2,370 & 535 (22.57) & 1 & $<0.001$ & 1 & $<\mathbf{0 . 0 0}$ \\
\hline 5 - 9 years & 3,083 & $826(26.79)$ & $\begin{array}{c}1.26 \text { (1.11 to } \\
1.42)\end{array}$ & $<0.001$ & $\begin{array}{c}1.26 \text { (1.11 to } \\
1.44)\end{array}$ & $<0.001$ \\
\hline $10-17$ years & 2,317 & $515(22.23)$ & $\begin{array}{c}0.98 \text { (0.85 to } \\
1.12)\end{array}$ & 0.776 & $\begin{array}{c}1.00(0.87 \text { to } \\
1.15)\end{array}$ & 0.977 \\
\hline Village & & & & $<0.001$ & & $<\mathbf{0 . 0 0}$ \\
\hline Bohero (BOH) & 358 & $86(24.02)$ & 1 & & 1 & \\
\hline Diagno (DIA) & 233 & $63(27.04)$ & $\begin{array}{c}1.17 \text { (o.80 to } \\
1.71)\end{array}$ & 0.409 & $\begin{array}{c}1.25(0.85 \text { to } \\
1.83)\end{array}$ & 0.258 \\
\hline $\begin{array}{l}\text { Dombourou } \\
\text { (DMB) }\end{array}$ & 345 & $106(30.72)$ & $\begin{array}{c}1.40(1.01 \text { to } \\
1.96)\end{array}$ & 0.047 & $\begin{array}{c}1.47(1.05 \text { to } \\
2.06)\end{array}$ & 0.026 \\
\hline Dontélo (DON) & 289 & $79(27.34)$ & $\begin{array}{c}1.19(0.83 \text { to } \\
1.70)\end{array}$ & 0.337 & $\begin{array}{c}1.21 \text { (o.84 to } \\
1.73)\end{array}$ & 0.301 \\
\hline Gongombiro (GBI) & 442 & $109(24.66)$ & $\begin{array}{c}1.04 \text { (o.75 to } \\
1.43)\end{array}$ & 0.834 & $\begin{array}{c}1.08 \text { (0.78 to } \\
1.50)\end{array}$ & 0.640 \\
\hline Kouloh (KOU) & 301 & $90(29.90)$ & $\begin{array}{c}1.35 \text { (0.95 to } \\
1.91)\end{array}$ & 0.090 & $\begin{array}{c}1.33 \text { (0.94 to } \\
1.89)\end{array}$ & 0.109 \\
\hline Kpalbalo (KPA) & 347 & $100(28.82)$ & $\begin{array}{c}1.28 \text { (0.92 to } \\
1.79)\end{array}$ & 0.149 & $\begin{array}{c}1.34(0.95 \text { to } \\
1.89)\end{array}$ & 0.093 \\
\hline Kpédia (KPE) & 359 & $61(16.99)$ & $\begin{array}{c}0.65(0.45 \text { to } \\
0.93)\end{array}$ & 0.020 & $\begin{array}{c}0.64(0.44 \text { to } \\
0.93)\end{array}$ & 0.019 \\
\hline Lobignonao (LOB) & 252 & $55(21.83)$ & $\begin{array}{c}0.88 \text { (o.6o to } \\
1.30)\end{array}$ & 0.526 & $\begin{array}{c}0.88 \text { (0.60 to } \\
1.30)\end{array}$ & 0.526 \\
\hline
\end{tabular}


Zongo et al./ Asymptomatic Malaria Carriage

\begin{tabular}{|c|c|c|c|c|c|c|}
\hline Moulé (MOU) & 276 & 56 (20.29) & $\begin{array}{c}0.81(0.55 \text { to } \\
1.18)\end{array}$ & 0.264 & $\begin{array}{c}0.80(0.55 \text { to } \\
1.18)\end{array}$ & 0.263 \\
\hline Nouvielgane (NAV) & 264 & $61(23.11)$ & $\begin{array}{c}0.95(0.65 \text { to } \\
1.38)\end{array}$ & 0.790 & $\begin{array}{c}0.93 \text { (o.64 to } \\
1.37)\end{array}$ & 0.721 \\
\hline Niombouna (NBO) & 277 & $24(8.66)$ & $\begin{array}{c}0.30(0.18 \text { to } \\
0.49)\end{array}$ & $<0.001$ & $\begin{array}{c}0.29(0.18 \text { to } \\
0.47)\end{array}$ & $<0.001$ \\
\hline Niombripo (NBR) & 351 & 66 (18.80) & $\begin{array}{c}0.73 \text { (0.51 to } \\
1.05)\end{array}$ & 0.091 & $\begin{array}{c}0.74(0.51 \text { to } \\
1.06)\end{array}$ & 0.102 \\
\hline Niaba (NIA) & 319 & $115(36.05)$ & $\begin{array}{l}1.78(1.28 \text { to } \\
2.49)\end{array}$ & 0.001 & $\begin{array}{c}1.93(1.38 \text { to } \\
2.71)\end{array}$ & $<0.001$ \\
\hline Nipodja (NIP) & 276 & $55(19.93)$ & $\begin{array}{c}0.79 \text { (0.54 to } \\
1.15)\end{array}$ & 0.220 & $\begin{array}{c}0.73(0.50 \text { to } \\
1.08)\end{array}$ & 0.114 \\
\hline Ouidiaro (OUI) & 301 & $67(22.26)$ & $\begin{array}{c}0.91(0.63 \text { to } \\
1.30)\end{array}$ & 0.593 & $\begin{array}{c}0.89 \text { (0.61 to } \\
1.29)\end{array}$ & 0.532 \\
\hline Palembera (PAL) & 214 & $61(28.50)$ & $\begin{array}{c}1.26(0.86 \text { to } \\
1.85)\end{array}$ & 0.236 & $\begin{array}{c}1.24(0.84 \text { to } \\
1.83)\end{array}$ & 0.275 \\
\hline $\begin{array}{l}\text { Perbalembiro } \\
\text { (PER) }\end{array}$ & 267 & $99(37.08)$ & $\begin{array}{c}1.86(1.32 \text { to } \\
2.64)\end{array}$ & $<0.001$ & $\begin{array}{c}1.96(1.38 \text { to } \\
2.79)\end{array}$ & $<0.001$ \\
\hline Sarambour (SAR) & 315 & $55(17.46)$ & $\begin{array}{l}0.67(0.46 \text { to } \\
0.98)\end{array}$ & 0.038 & $\begin{array}{c}0.70(0.48 \text { to } \\
1.02)\end{array}$ & 0.065 \\
\hline Sidmoukar (SID) & 322 & $54(16.77)$ & $\begin{array}{c}0.64(0.44 \text { to } \\
0.93)\end{array}$ & 0.020 & $\begin{array}{c}0.66(0.45 \text { to } \\
0.96)\end{array}$ & 0.032 \\
\hline Sinkiro (SKI) & 210 & 46 (21.90) & $\begin{array}{c}0.89 \text { (0.59 to } \\
1.33)\end{array}$ & 0.564 & $\begin{array}{c}0.90(0.59 \text { to } \\
1.35)\end{array}$ & 0.607 \\
\hline Soussoubro (SOU) & 174 & $31(17.82)$ & $\begin{array}{c}0.69(0.43 \text { to } \\
1.08)\end{array}$ & 0.106 & $\begin{array}{c}0.69(0.43 \text { to } \\
1.09)\end{array}$ & 0.113 \\
\hline Tordiero (TDI) & 175 & $52(29.71)$ & $\begin{array}{c}1.34 \text { (o.89 to } \\
2.00)\end{array}$ & 0.160 & $\begin{array}{c}1.31(0.87 \text { to } \\
1.98)\end{array}$ & 0.194 \\
\hline Tiarkiro (TIA) & 228 & $42(18.42)$ & $\begin{array}{c}0.71(0.47 \text { to } \\
1.08)\end{array}$ & 0.111 & $\begin{array}{c}0.73(0.48 \text { to } \\
1.11)\end{array}$ & 0.136 \\
\hline Yelbelela (YBE) & 236 & $50(21.19)$ & $\begin{array}{c}0.85(0.57 \text { to } \\
1.26)\end{array}$ & 0.421 & $\begin{array}{c}0.85(0.57 \text { to } \\
1.26)\end{array}$ & 0.417 \\
\hline Yellela (YLE) & 403 & $125(31.02)$ & $\begin{array}{c}1.42(1.03 \text { to } \\
1.96)\end{array}$ & 0.032 & $\begin{array}{c}1.45 \text { (1.05 to } \\
2.01)\end{array}$ & 0.025 \\
\hline $\begin{array}{l}\text { Slept under bednet } \\
\text { No }\end{array}$ & 2,171 & $560(25.79)$ & 1 & $<0.001$ & 1 & 0.248 \\
\hline Yes & 5,599 & $1,316(23.5)$ & $\begin{array}{l}0.88 \text { (0.79 to } \\
0.99)\end{array}$ & 0.034 & $\begin{array}{c}0.92(0.79 \text { to } \\
1.06)\end{array}$ & 0.248 \\
\hline
\end{tabular}

Note: Goodness of fit for the adjusted model: Chi2(774) $=1176.79 ; \mathrm{p}<0.001$

\section{Prevalence of asymptomatic carriers per period}

Asymptomatic malaria carriage significantly varied in relation to the survey, the sociodemographic parameters and bednet use categories (respective $\mathrm{p}<0.05$ ).

The proportion of asymptomatic carriers within 5-9 years old children (27\%) was significantly higher than that in children aged 6 to 59 months (22\%) and in children aged from 10 to 17 years ( $p$ $<0.001)$. This trend was observed in December 2016 and June 2017 whereas there was no significant difference among age groups in September 2016.

The asymptomatic malaria rates were higher during the December 2016 survey relative to the 2 others surveys regardless the age, gender or bed net use.

Bed net use the night before the survey, which is a proxy of the general use of LLINs was associated with a lower rate of asymptomatic malaria in September 2016 ((26.67\% vs $17.23 \%$ for users vs non-users, $\mathrm{p}<0.001)$. Finally, subclinical malaria carriage among the subjects statistically differ- 
Zongo et al./ Asymptomatic Malaria Carriage

ed per area of residence and across surveys (table 4).

Table 4. Distribution of asymptomatic malaria per sociodemographic characteristics and bednet utilization across the three surveys

\begin{tabular}{|c|c|c|c|c|c|c|c|c|c|}
\hline \multirow{2}{*}{ Characteristics } & \multicolumn{2}{|c|}{ Sept. 2016} & \multicolumn{2}{|c|}{ Dec. 2016} & \multicolumn{2}{|c|}{ June 2017} & \multicolumn{2}{|c|}{ Overall } & \multirow[t]{2}{*}{$\mathbf{p}$} \\
\hline & $\mathbf{N}$ & $\%$ & $\mathbf{N}$ & $\%$ & $\mathbf{N}$ & $\%$ & $\mathbf{N}$ & $\%$ & \\
\hline Age group & & & & & & & & & $<0.001^{*}$ \\
\hline $6-59$ months & 152 & 17.92 & 231 & 28.77 & 152 & 24.14 & 535 & 22.57 & \\
\hline $5-9$ years & 206 & 19.07 & 340 & 33.4 & 280 & 28.43 & 826 & 26.79 & \\
\hline $10-17$ years & 144 & 15.81 & 206 & 26.65 & 165 & 26.07 & 515 & 22.23 & \\
\hline $\mathrm{p}$ & 0.159 & & & & & & $<0.001^{*}$ & & \\
\hline \multicolumn{10}{|l|}{ Gender } \\
\hline Male & 295 & 20.8 & 393 & 30.61 & 285 & 26.81 & 973 & 25.84 & $<0.001^{*}$ \\
\hline Female & 207 & 14.57 & 384 & 29.31 & 312 & 24.49 & 903 & 22.55 & $<0.001^{*}$ \\
\hline $\mathrm{p}$ & $0.000^{*}$ & & & & & & $0.001^{*}$ & & \\
\hline \multicolumn{10}{|l|}{ Slept under bednet } \\
\hline No & 36 & 26.67 & 140 & 30.3 & 384 & 24.4 & 560 & 25.79 & 0.037 \\
\hline & 466 & 17.23 & 637 & 29.88 & 213 & 27.92 & 1,316 & 23.5 & $<0.001^{*}$ \\
\hline $\mathrm{p}$ & $0.001^{*}$ & & & & & & $0.034^{*}$ & & \\
\hline \multicolumn{10}{|l|}{ Village } \\
\hline Bohero (BOH) & 36 & 31.03 & 33 & 25.78 & 17 & 14.91 & 86 & 24.02 & $0.014^{*}$ \\
\hline Dangbara (DAN) & 11 & 12.22 & 31 & 38.75 & 26 & 39.39 & 68 & 28.81 & $<0.001^{*}$ \\
\hline Diagno (DIA) & 15 & 16.48 & 26 & 32.91 & 22 & 34.92 & 63 & 27.04 & $0.014^{*}$ \\
\hline Dombourou (DMB) & 35 & $27 \cdot 34$ & 44 & 44.44 & 27 & 22.88 & 106 & 30.72 & $0.002^{*}$ \\
\hline Dontélo (DON) & 26 & 28.26 & 18 & 20.93 & 35 & 31.53 & 79 & 27.34 & 0.247 \\
\hline Gongombiro (GBI) & 43 & 23.76 & 43 & 29.66 & 23 & 19.83 & 109 & 24.66 & 0.175 \\
\hline Kouloh (KOU) & 31 & 30.69 & 20 & 19.23 & 39 & 40.63 & 90 & 29.9 & $0.004^{*}$ \\
\hline Kpalbalo (KPA) & 20 & 14.08 & 41 & 39.81 & 39 & 38.24 & 100 & 28.82 & $<0.001^{*}$ \\
\hline Kpédia (KPE) & 16 & 12.21 & 35 & 27.13 & 10 & 10.1 & 61 & 16.99 & $0.001^{*}$ \\
\hline Lobignonao (LOB) & 4 & 4.4 & 24 & 32.88 & 27 & 30.68 & 55 & 21.83 & $<0.001^{*}$ \\
\hline Moulé (MOU) & 7 & 8.05 & 32 & $35 \cdot 96$ & 17 & 17 & 56 & 20.29 & 0.101 \\
\hline Nouvielgane (NAV) & 13 & 14.94 & 38 & 43.18 & 10 & 11.24 & 61 & 23.11 & $<0.001^{*}$ \\
\hline Niombouna (NBO) & 5 & $5 \cdot 32$ & 11 & 10.28 & 8 & 10.53 & 24 & 8.66 & 0.365 \\
\hline Niombripo (NBR) & 10 & 7.69 & 30 & 24.59 & 26 & 26.26 & 66 & 18.8 & $<0.001^{*}$ \\
\hline Niaba (NIA) & 34 & 24.64 & 43 & $45 \cdot 74$ & 38 & 43.68 & 115 & 36.05 & $0.001^{*}$ \\
\hline Nipodja (NIP) & 4 & 5.26 & 29 & 25.22 & 22 & 25.88 & 55 & 19.93 & $0.001^{*}$ \\
\hline Ouidiaro (OUI) & 6 & 5.17 & 54 & 50.47 & 7 & 8.97 & 67 & 22.26 & $<0.001^{*}$ \\
\hline Palembera (PAL) & 15 & 21.43 & 29 & 40.28 & 17 & 23.61 & 61 & 28.5 & $0.024^{*}$ \\
\hline Perbalembiro(PER) & 47 & 40.17 & 24 & 27.59 & 28 & 44.44 & 99 & 37.08 & $0.070^{*}$ \\
\hline Sarambour (SAR) & 31 & 24.22 & 20 & 19.8 & 4 & 4.65 & 55 & 17.46 & $0.001^{*}$ \\
\hline Sidmoukar (SID) & 12 & 9.3 & 19 & 21.11 & 23 & 22.33 & 54 & 16.77 & $0.013^{*}$ \\
\hline Sinkiro (SKI) & 18 & 26.09 & 19 & 21.84 & 9 & 16.67 & 46 & 21.9 & 0.456 \\
\hline Soussoubro (SOU) & 9 & 13.43 & 11 & 17.74 & 11 & 24.44 & 31 & 17.82 & 0.328 \\
\hline Tordiero (TDI) & 3 & 4.76 & 27 & 42.86 & 22 & 44.9 & 52 & 29.71 & $<0.001^{*}$ \\
\hline Tiarkiro (TIA) & 18 & 21.95 & 17 & 22.08 & 7 & 10.14 & 42 & 18.42 & 0.105 \\
\hline Yelbelela (YBE) & 2 & 2.35 & 31 & 36.05 & 17 & 26.15 & 50 & 21.19 & $<0.001^{*}$ \\
\hline Yellela (YLE) & 31 & 22.46 & 28 & 23.14 & 66 & 45.63 & 125 & 31.02 & $<0.001^{*}$ \\
\hline $\mathrm{p}$ & $\underset{*}{<0.001}$ & $\begin{array}{c}<0.001 \\
*\end{array}$ & $<\underset{*}{<0.001}$ & & & & $<0.001^{*}$ & & \\
\hline
\end{tabular}




\section{Relation between asymptomatic and clinical malaria}

Figure 1 displays the compared prevalence of symptomatic versus asymptomatic malaria per time of the survey. Asymptomatic malaria prevalence among subjects was comparable to that of the clinical form in
September 2016. In December 2016 and June 2017, subclinical malaria was significantly more prevalent. Also, there was a linear decline in clinical malaria prevalence from September 2016 to June 2017 (beta = 8.5)

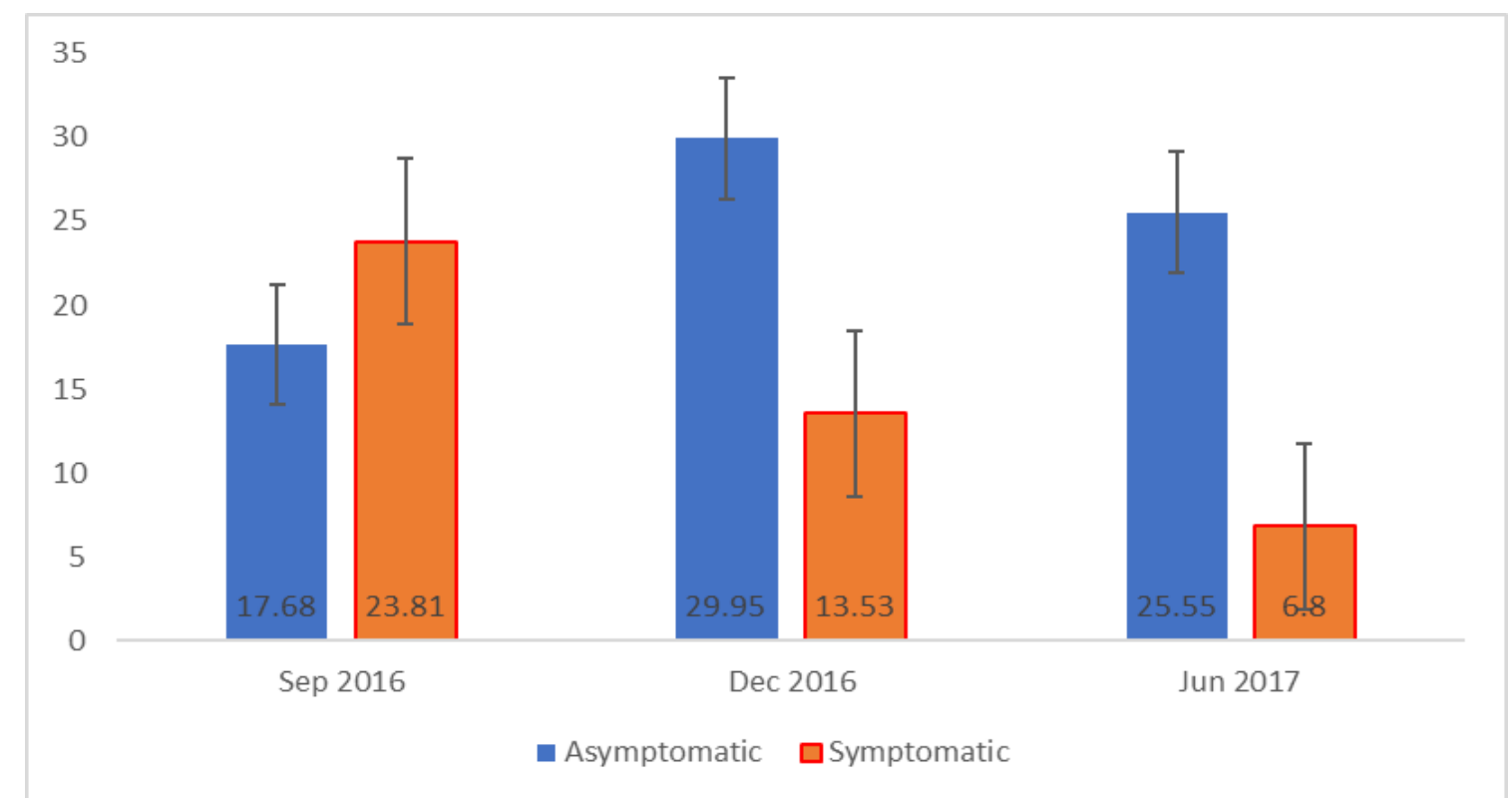

Figure 1. Prevalence of asymptomatic carriers and clinical cases per period

\section{DISCUSSION}

Our study showed a high burden of asymptomatic malaria, characterized by a prevalence of parasitemia ranging from $31.6 \%$ to $43.5 \%$. Such a prevalence has been reported in endemic areas including sub-Saharan Africa (Taylor-Robinson, 2000; Ibekwe et al., 2009; Steenkeste et al., 2010). Recently, Owusu et al. in 2017 (Owusu et al., 2017) found a pattern of asymptomatic malaria carriage from $16.3 \%$ among the under-5 and to $25.6 \%$ among children aged 11 to 15 years. Such prevalence of asymptomatic malaria in endemic settings is often correlated to the development of partial immunity which allows controlling for the development of clinical symptoms. Also, such a reservoir of asymptomatic carriers can be due to parasite manipulation to maintain its transmission from person to person (Busula et al., 2017).

In our study, age, gender, transmission season, place of residence, and bed net use was significantly associated with asymptomatic malaria. Previous reports have found a high prevalence of asymptomatic malaria in males than in females (TaylorRobinson, 2000; Dinko et al., 2018). This might be because in our setting, males are more exposed to outdoor activities than females and are likely to experience increased risk of infective mosquito bites.

Children aged 5 to 9 years had the highest prevalence of the disease, regardless of transmission season compared to those aged 6 months to less than 5 years and those 10 and above. Owusu also found an age difference in the carriage of asymp- 
tomatic malaria in Ghana in 2017 (Owusu et al., 2017). However, our results differ by the fact in our case we have a reverse " $U$ shape" type of prevalence across the age groups. Younger children could still have, for some, protective immunoglobulins gain from breastfeeding that might protect them from developing symptomatic malaria cases. The protective role was found in several studies. Hence, older children who are repeatedly exposed to mosquito bites develop an immune response along with the presence of nitric oxide (NO) and leucocyte NO synthase type 2 in asymptomatic children helps to prevent malaria signs and symptoms (Anstey and Smith, 1999; Busula et al., 2017).

Sleeping under a bednet the night before the survey was found to be protective against asymptomatic malaria. Indeed, the prevalence of asymptomatic malaria was lower in those who slept under a treated bednet; indeed, bednet is an effective tool in malaria for control in reducing both asymptomatic and clinical malaria (Wangdi et al., 2014; Mukhtar et al., 2018). In a systematic review modeling the effect of bednet coverage, insecticide-treated nets were found to reduce Plasmodium falciparum carriage by $17 \%$.

High prevalence of asymptomatic carriage was found in December which corresponds in fact to the end of the transmission compared to the period of high transmission of September, and this seasonal pattern in asymptomatic malaria carriage is vastly described in the literature and is linked to the decrease in mosquito bites, parasite's density in the blood and other biological factors (Tiedje et al., 2017; Ayanful-Torgby et al., 2018).

Our study retrieved a spatial distribution pattern within Diebougou's district area. Asymptomatic malaria showed an uneven distribution by the village of residence across all data collection periods. We noted that for only 8 villages, this prevalence did not differ according to the season of data collection. These villages were either characterized by their location close to main or secondary roads, or by the paucity of streams, rivers and another wild water network. This is in accordance with the environmental components of malaria risk factors. Villages close to roads have the characteristics to have a cleaner environment than others. Besides, people in these areas have more access to information and protective means. Also, the lack of rivers, streams, and stagnant water in the environment reduces breeding sites for mosquitoes and conversely the prevalence of malaria parasite carriage. Spatial distribution of malaria prevalence was already shown across health districts in Burkina Faso, with Diebougou's district classified among the highest prevalent (Ouedraogo et al., 2015). Our study is adding the fact that we must account for heterogeneity within the same district when planning for malaria control strategies.

Our study has tried to capture the burden of asymptomatic malaria through point prevalence surveys at three different key points; this may have missed some variations of the prevalence. Furthermore, we did not reach the full potential of enrollment as expected from the initial survey. Despite these limitations, the study has the merit to describe the baseline malaria burden prior to the initiation of a trial and thus the result could guide further investigation on malaria and its epidemiology in the area. We conducted three-point prevalence surveys to evaluate the burden of asymptomatic malaria prior the implementation of a large study aiming at investigating the benefit of additional intervention against malaria in a context of universal LLINs coverage and widespread resistance to insect- 
cides. Asymptomatic malaria was prevalent in the area and was decreasing as we move toward the end of the transmission season and the prevalence was even higher in older children. Further investigation would evaluate the progress of asymptomatic carriers toward clinical malaria, either severe or uncomplicated.

\section{AUTHORS CONTRIBUTION}

IZ, AS, MO wrote the first draft of the manuscript and contributed for the data acquisition, ENS critically read and approved the last version, $\mathrm{AD}$ analyzed and critically reviewed the manuscript, $\mathrm{CD}, \mathrm{NM}$ and $\mathrm{RKD}$ designed the study and critically read the manuscript.

\section{FUNDING AND SPONSORSHIP}

This research was funded by the French Initiative 5\% Expertise France. The Grant Number is 15 SANIN213.

\section{ACKNOWLEDGEMENT}

We are grateful to the study field team (nurses and technicians) who collected the data, the administration of the health district of Diebougou for their strong collaboration and all the inhabitants of the health district of Diebougou who took part in the surveys and participated actively in the data collection.

\section{CONFLICT OF INTEREST}

None.

\section{REFERENCE}

Anstey KJ, Smith GA (1999). Interrelationships among biological markers of aging, health, activity, acculturation, and cognitive performance in late adulthood. Psychol Aging. 14(4): 605618. doi: 10.1037/0882-7974.14.4.605.

Ayanful-Torgby R, Quashie NB, Boampong
JN, Williamson KC, Amoah LE (2018). Seasonal variations in Plasmodium falciparum parasite prevalence assessed by varying diagnostic tests in asymptomatic children in southern Ghana. PLoS ONE. 13(6). 114. doi: 10.1371/journal.pone.0199172.

Bereczky S, Liljander A, Rooth I, Faraja L, Granath F, Montgomery S, Mand Färnert A (2007). Multiclonal asymptomatic Plasmodium falciparum infections predict a reduced risk of malaria disease in a Tanzanian population. Microbes and Infection. 9(1): 103-110. doi: 10.1016/j.micinf.2006.10.014.

Bousema T, Okell L, Felger I, Drakeley C (2014). Asymptomatic malaria infections: public health relevance. NPG. 12(12): 833-840. doi: $10.1038 / \mathrm{nrmi}^{-}$ cro3364.

Busula AO, Verhulst NO, Bousema T, Takken W, Boer JGD (2017). Mechanisms of Plasmodium-Enhanced Attraction of Mosquito Vectors. Trends Parasitol. 33(12): 961-973. doi: 10.1016/j.pt.2017.08.010.

Chen I, Clarke SE, Gosling R, Hamainza B, Killeen G, Magill A, O’Meara W, et al. (2016). Asymptomatic Malaria: A Chronic and Debilitating Infection That Should Be Treated. PLoS Med. 13(1): e1001942. doi: 10.1371/journal.pmed.1001942.

Dinko B, Amakpa E, Kweku M, Amoah P, Tampuori J, Adjuik M, Awandare GA, et al. (2018). Plasmodium falciparum malaria cases detected for prompt treatment by rapid diagnostic tests in the Ho Teaching Hospital of the Volta Region of Ghana. Parasite Epidemiol. Control. 3(3): eo0072. doi: 10.1016/j.parepi.2018.eooo72.

Epopa PS, Collins CM, North A, Millogo AA, Benedict MQ, Tripet F, Diabate A 
(2019). Seasonal malaria vector and transmission dynamics in western Burkina Faso. Malar. J. 1-13. doi: 10.1186/s12936-019-2747-5.

Ganguly S, Saha P, Guha SK, Biswas A, Das S, Kundu PK, Maji AK (2013). High Prevalence of Asymptomatic Malaria in a Tribal Population in Eastern India. J. Clin. Microbiol. 51(5): 14391444. doi: 10.1128/JCM.03437-12.

Gouagna LC, Ferguson HM, Okech BA, Killeen GF, Kabiru EW, Beier JC, Githure JI, et al. (2004). Plasmodium falciparum malaria disease manifestations in humans and transmission to Anopheles gambiae: a field study in Western Kenya. Parasitology. 128(3): 235-243. doi: 10.1017/Soo3118200300444X.

Gudo ES, Prista A, Jani IV (2013). Impact of asymptomatic Plasmodium falciparum parasitemia on the imuno hematological indices among school children and adolescents in a rural area highly endemic for Malaria in southern Mozambique. BMC Infect Dis. 13:244. doi: 10.1186/1471-233413-244.

Ibekwe AC, Okonko IO, Onunkwo AI, Ogun AA, Udeze AO (2009). Comparative prevalence level of plasmodium in freshmen (first year students) of Nnamdi Azikwe University in Awka, South-Eastern, Nigeria. MJM. doi: 10$.21161 / \mathrm{mjm} .16409$.

Imbert P, Gérardin P, Rogier C, Ka AS, Jouvencel P, Brousse V, Guyon P (2002). Severe falciparum malaria in children: a comparative study of 1990 and 20oo WHO criteria for clinical presentation, prognosis and intensive care in Dakar, Senegal. Trans. R. Soc. 96(3): 278-281. doi: 10.1016/Soo35-9203(02)90099-4.

Lindblade KA, Steinhardt L, Samuels A,
Kachur SP, Slutsker L (2013). The silent threat: asymptomatic parasitemia and malaria transmission. ERATCK. 11(6): 623-639. doi: 10.1586/eri.13.45.

Marsh K, Forster D, Waruiru C, Mwangi I, Winstanley M, Marsh V, Newton C, et al. (1995). Indicators of Life-Threatening Malaria in African Children. N Engl J Med. 332(21): 1399-1404. doi: 10.1056/NEJM199505253322102.

Ministry of Health BF (2016a). Annuaire statistique 2016. SG/DGESS. http://cns.bf/IMG/pdf/annuaire_2016_ms_ signe.pdf. Accessed on February 10 2022.

Ministry of Health BF (2016b). Diebougou health district 2016 action plan.

Mukhtar AYA, Munyakazi JB, Ouifki R, Clark AE (2018). Modelling the effect of bednet coverage on malaria transmission in South Sudan. PLoS ONE 13(6): e0198280. doi: 10.1371/journal.pone.019828.

Njama-Meya D, Kamya MR, Dorsey G (2004). Asymptomatic parasitaemia as a risk factor for symptomatic malaria in a cohort of Ugandan children. Trop Med Int Health. 9(8): 862-868. doi: $10.1111 / \mathrm{j} .1365-3156.2004 .01277 .-$ $\mathrm{x}$.

Ouedraogo AL, Bastiaens GJH, Tiono AB, Guelbeogo WM, Kobylinski KC, Ouedraogo A, Barry A, et al. (2015). Efficacy and Safety of the Mosquitocidal Drug Ivermectin to Prevent Malaria Transmission After Treatment: A Double-Blind, Randomized, Clinical Trial. Clin. Infect. Dis. 6o(3): 357-365. doi: 10.1093/cid/ciu797.

Owusu EDA, Brown CA, Grobusch MP, Mens P (2017). Prevalence of Plasmodium falciparum and non-P. Falciparum infections in a highland district in Ghana, and the influence of HIV 
and sickle cell disease. Malar J. 10-17. doi: 10.1186/s12936-017-1823-y.

Schneider P, Bousema JT, Gouagna LC, Otieno S, Vegte-Bolmer MVD, Omar SA, Sauerwein RW (2007). Submicroscopic Plasmodium falciparum gametocyte densities frequently result in mosquito infection. Am. J. Trop. Med. 76(3): 470-474. doi: 10.4269/ajtmh.2007.76.470.

Soma DD, Zogo BM, Somé A, Tchiekoi BN, Hien DF de S, Pooda HS, Coulibaly S, et al. (2020). Anopheles bionomics, insecticide resistance and malaria transmission in southwest Burkina Faso: A pre-intervention study. PLoS ONE. 15(8): eo236920. doi: 10.1371/journal.pone.0236920.

Steenkeste N, Rogers WO, Okell L, Jeanne I, Incardona S, Duval L, Chy S, et al. (2010). Sub-microscopic malaria cases and mixed malaria infection in a remote area of high malaria endemicity in Rattanakiri province, Cambodia: implication for malaria elimination. BMJ. 1-11. doi: 10.1186/14752875-9-108.

Tadesse FG, Hoogen L Van Den, Lanke K, Schildkraut J, Tetteh K, Aseffa A, Mamo H, et al. (2017). The shape of the iceberg: quantification of submicroscopic Plasmodium falciparum and Plasmodium vivax parasitaemia and gametocytaemia in five low endemic settings in Ethiopia. Malar J. 1-11. doi: 10.1186/s12936-017-1749-4.

Taylor-Robinson AW (2000). Increased production of acute-phase proteins corresponds to the peak parasitaemia of primary malaria infection. Parasitol. Int. 48(4): 297-301. doi: 10.10-
16/S1383-5769(99)ooo29-X.

Tiedje KE, Oduro AR, Agongo G, Anyorigiya $\mathrm{T}$, Azongo $\mathrm{D}$, Awine $\mathrm{T}$, Ghansah A, et al. (2017). Seasonal Variation in the Epidemiology of Asymptomatic Plasmodium falciparum Infections across Two Catchment Areas in Bongo District, Ghana. Am J Trop Med Hyg. 97(1): 199-212. doi: 10.4269/ajtmh.16-0959.

Tiono AB, Kangoye DT, Rehman AM, Kargougou DG, Kaboré Y, Diarra A, Ouedraogo E, et al. (2014). Malaria incidence in children in South-West Burkina Faso: comparison of active and passive case detection methods. PloS One. 9(1): e86936. doi: 10.1371/journal.pone.0086936.

Wangdi K, Gatton ML, Kelly GC, Clements ACA (2014). Prevalence of asymptomatic malaria and bed net ownership and use in Bhutan, 2013 : a country earmarked for malaria elimination. BMJ. 1-10. doi: 10.1186/1475-2875-13-352.

WHO (2018). High burden to high impact A targeted malaria response. A malaria targeted response. https://apps.who.int/iris/bitstream/handle/10665/275 868/WHO-CDS-GMP-2018.25-eng.pdf. Accessed on February 102022.

WHO (2020). WHO World Malaria Report https://www.who.int/publications/i/i tem/9789240015791. Accessed on February 102022.

WHO (2015). Malaria Policy Advisory Committee to the WHO: conclusions and recommendations of seventh biannual meeting (March 2015). Malar J. 14(1): 295. doi: 10.1186/s12936-015-0787-Z. 